\title{
Serum Zinc Level before and after Low Carbohydrate Diet in Male and Female Overweight and Obese Ain Shams University Medical Students
}

\author{
AHMED N. HASSAN, M.D.*; YASMIN M. ABOUL-ELA, M.D.* and MENNATALLAH A.A. SHETAYA, M.Sc.** \\ The Department of Clinical Pharmacology, Faculty of Medicine, Ain Shams University* and \\ Clinical Nutritionist at Agouza Police Hospital**
}

\begin{abstract}
Background: Overweight and obesity are defined as abnormal or excessive fat accumulation that may impair health. Body mass index (BMI) is a simple index of weightfor-height that is commonly used to classify overweight and obesity in adults. It is defined as a person's weight in kilograms divided by the square of his height in meters $\left(\mathrm{kg} / \mathrm{m}^{2}\right)$.

Aim of Study: Our study was conducted to assess serum zinc level before and after low carbohydrate diet program over 40 days.

Patients and Methods: The study included 30 overweight and obese students with age range from (20-26 years) 22 females and 8 males selected randomly from Faculty of medicine Ain Shams University during 2019-2020 after exclusion of students with body mass index below $25 \mathrm{~kg} / \mathrm{m}^{2}$ and students with constipation, fatigue, diarrhea, heartburn, gas, nausea, vomiting, appetite changes or headache.

Results: Serum zinc levels in overweight and obese students were low, most of participants have zinc deficiency which improved with the decrease of BMI after low carbohydrate diet program this ensures that serum zinc levels affected by body weight and body mass index. Our single arm open label clinical trial showed that serum zinc level improved with decrease in body mass index among overweight and obese medical students after applying low carbohydrate diet program over the same period of time.

Conclusion: Taken together the benefits of carbohydrate restriction in overweight/obese patients and the altered serum zinc levels in these patients, it was tempting to further serum zinc levels before and after low carbohydrate diet in overweight and obese youth, where to our knowledge, this is the first clinical study targeting this subject in Egypt.
\end{abstract}

Key Words: Zinc - Low - Carbohydrate diet - Overweight Obesity.

\section{Introduction}

OVERWEIGHT and obesity are defined as abnormal or excessive fat accumulation leading to

Correspondence to: Dr. Mennatallah A.A. Shetaya, E-Mail: doctoramenna90@gmail.com health impairment. Body mass index (BMI), a simple index of weight-for-height commonly used to classify overweight and obesity in adults, is defined as a person's weight in kilograms divided by the square of his height in meters $\left(\mathrm{kg} / \mathrm{m}^{2}\right)$. For adults, the World Health Organization (WHO) defines overweight and obesity as follows: Overweight is a BMI greater than or equal to 25 and Obesity is a BMI greater than or equal to 30 [1].

Currently, obesity is the fifth greatest risk factor for mortality. The increase in obesity rates presents a major public health concern as it is associated with a number of co-morbidities such as cardiovascular diseases, hypertension, stroke, type 2 diabetes mellitus (T2DM), dyslipidemia, osteoarthritis, as well as some cancers [2] .

Nutritional disorders and obesity commonly co-exist, studies have attempted to clarify the disturbance in mineral metabolism in the presence of obesity. Some studies have shown that zinc ( $\mathrm{Zn}$ ) concentrations in plasma and erythrocytes are reduced in obese people whereas $\mathrm{Zn}$ supplementation improves various physiological functions in such patients [3].

Indeed $\mathrm{Zn}$ is required for many biological functions including DNA synthesis, cell division, gene expression, and the activity of various enzymes in humans and animals [4].

Dietary carbohydrate restriction has long become a topic of interest to both overweight and obese patients as well as clinicians. In lowcarbohydrate diets, energy from carbohydrate is generally replaced by energy from fat. Lowcarbohydrate diet is defined as $<130 \mathrm{~g} / \mathrm{d}$ or $<26 \%$ of total daily energy consumption [5]. Different potential benefits of carbohydrate restriction may 
include fat mobilization, oxidation and reductions in the TG/HDL ratio, a marker of insulin resistance [6].

Taken together the benefits of carbohydrate restriction in overweight/obese patients and the altered serum $\mathrm{Zn}$ levels in these patients, it was tempting to further investigate serum $\mathrm{Zn}$ levels before and after low carbohydrate diet in overweight/obese youth, where to our knowledge, this is the first clinical study targeting this subject in Egypt.

\section{Aim of the work:}

This study is a part of The Nutritional Assessment of Medical Students of Ain Shams University (NAMS/ASU). The project was designed to evaluate the nutritional status of the undergraduate medical students. The aim of the present work was to evaluate serum zinc levels before and after 40 days of low carbohydrate diet in overweight and obese medical students in Faculty of Medicine, Ain Shams University.

\section{Patients and Methods}

This study is a part of the Nutritional Assessment of Medical Students of Ain Shams University (NAMS/ASU): The project was designed to evaluate the nutritional status of the undergraduate medical students. All participants were subjected to interview questionnaires, including data: Name, age, sex, study grade, past medical history and family history.

Dietary recall: $24 \mathrm{hrs}$ food recall, food frequency and related iron intake. All data were analyzed using food composition table National Nutritional Institute (NNI). General examination included: Hair, skin, eye, teeth, gum, lips, neck, tongue and parotid.

Assessment of the following anthropometric measurements: Weight in kilogram (kg): The participants being bare-foot and in minimal clothing, weight was measured with electronic scales (InBody 770). Height in centimeters (cm): Measured by portable stadiometers with the participant feet placed together with heels, buttocks and shoulder blades against the stick and head positioned in the Frankfurt horizontal plane. Body mass index (BMI): is defined as weight (in $\mathrm{kg}$ ) divided by height (in $\mathrm{m}^{2}$ ). Waist circumference (WC) in centimeters $(\mathrm{cm})$ : Waist girth was measured (underwear) with a stretchless tape in standing position after normal expiration, midway between the caudal part of the lateral costal arch and the iliac crest. International Diabetes Federation (IDF) defined the optimal waist circumference cutoffs 100.5 centemetre and 96.25 centemetre for Egyptian men and women, respectively. Cut off points for waist circumference are $94 \mathrm{~cm}$ in males and $80 \mathrm{~cm}$ in females determined for European men and women (World Health Organization standard). Studies investigating South Americans recommended waist circumference cutoff points of $88-90 \mathrm{~cm}$ for men, and $83-84 \mathrm{~cm}$ for women [7]. Hip circumference in centimeters $(\mathrm{cm})$ : hip girth was measured at the symphysis trochanter level. Mean hip circumference ranged from 94$105 \mathrm{~cm}$ in males and $97-108 \mathrm{~cm}$ in females. Bioelectrical impedance segmental analysis using InBody 770 . The following measurement were estimated weight ( $\mathrm{kg})$, BMI, muscle mass $(\mathrm{kg})$, body fat percent $(\%)$, fat free mass $(\mathrm{kg})$, muscle mass $(\mathrm{kg})$ and total body water (\%), (In-Body USA).

The study included medical students with BMI $>25 \mathrm{~kg} / \mathrm{m}^{2}$, while others with BMI $>25 \mathrm{~kg} / \mathrm{m}^{2}$ were excluded from the study.

\section{-Pre-intervention baseline assessment:}

Serum Zinc level measured without any pretreatment and Body mass index (BMI).

\section{Intervention:}

A 40 days low carbohydrate diet, including less than $26 \%$ of the total calories from carbohydrate, was implemented to 30 overweight and obese medical students on a weekly base and tailored individually to meet the nutritional requirements, medical condition, food preferences, and socioeconomic status of each student (Low carbohydrate program 2018) http://www.lowcarbprogram.com [assessed 16 December 2018]. Weekly monitoring of adherence of participating students and of the emergence of any complaint was performed.

- Study intervention period: 40 days.

- Outcome:

1- BMI.

\section{2- Serum Zinc Level.}

Adverse events: Constipation, fatigue, diarrhea, heartburn, gas, nausea, vomiting, appetite changes or headache were reported and withdrawal from the trial was allowed when adequate control of adverse effects couldn't be achieved.

Ethical considerations: A written informed consent was obtained from each student after explaining the aim of the study $\&$ all the procedures that will be done. Privacy \& confidentiality were concerned. Approval was obtained from the ethical committee. Follow-up of medical students was 
proceeded on weekly base by phone or by interview at the beginning and the end of the program.

Outcome: After 40 days, blood samples were collected for measuring zinc levels and assessing results before and after the low carbohydrate diet.

\section{Sample collection:}

Samples were collected from each student under complete aseptic conditions, using sterile vacutainers. Quantitative determination of Zinc in human serum was done. Zinc forms a red chelate complex with 2-(5-Brom-2-pyridylazo)-5-(N-propyl-Nsulfo-propylamino)-phenol. The increase of absorbance can be measured and is proportional to the concentration of total zinc in the sample.

\section{Statistical analysis:}

Recorded data were analyzed using the statistical package for social sciences, version 20.0 (SPSS Inc., Chicago, Illinois, USA). Quantitative data were expressed as mean \pm standard deviation (SD). Qualitative data were expressed as frequency and percentage.

Paired sample $t$-test of significance was used when comparing between related sample. The confidence interval was set at $95 \%$ and the margin of error accepted was set at $5 \%$. So, the $p$-value of $<0.05$ was considered significant.

\section{Results}

\section{Demographic characteristics \& anthropometric measurements:}

The present study was conducted on 30 medical students who participated in The Nutritional Assessment of Medical Students of Ain Shams University (NAMS/ASU). Details of the patients including, age and gender, are shown in Table (1). More than half $(n=22 ; 73.3 \%)$ of participants were females while $26.7 \%(n=8)$ were males. The mean (SD) values for age were 22.9 (1.42) years old with a minimum of 20 and a maximum of 26 years old. Baseline anthropometric measurements' ranges are shown in Table (2).

Table (1): Distribution of study group according to their demographic data regarding sex and age $(n=30)$.

\begin{tabular}{ll}
\hline Demographic data & Total $(\mathrm{n}=30)$ \\
\hline Sex: & \\
Female & $22(73.3 \%)$ \\
Male & $8(26.7 \%)$ \\
Age (years): & \\
Range & $20-26$ \\
Mean \pm SD & $22.90 \pm 1.42$ \\
\hline
\end{tabular}

Table (2): Study group anthropometric measurements; Range of Height, Weight, Waist circumference, Hip Circumference and BMI.

\begin{tabular}{lll}
\hline Anthropometric measurements & Range & Mean \pm SD \\
\hline Height & $153-182$ & $165.43 \pm 9.11$ \\
Weight & $65-116$ & $85.94 \pm 11.98$ \\
Waist circumference & $85-113$ & $97.32 \pm 7.13$ \\
Hip circumference & $93-134$ & $113.52 \pm 10.65$ \\
BMI before & $26.8-37.2$ & $31.65 \pm 3.08$ \\
\hline
\end{tabular}

The effect of 40-days low carbohydrate diet on weight of participating medical students:

Following a regimen of 40-days low carbohydrate diet resulted in a statistically significant weight reduction $(80.04 \pm 11.27)$ in the study group compared to the baseline weight mean (85.94 \pm 11.98) as shown in Table (3).

Table (3): A comparison between study group weight range before and after 40 days of low carbohydrate diet.

\begin{tabular}{lccccc}
\hline Weight Range & Mean $\pm \mathrm{SD}$ & $\begin{array}{c}\text { Mean } \\
\text { difference }\end{array}$ & $t$-test & $p$-value \\
\hline Before & $65-116$ & $85.94 \pm 11.98$ & 5.90 & 14.154 & $<0.001^{* *}$ \\
After & $62-110.5$ & $80.04 \pm 11.27$ & & & \\
\hline
\end{tabular}

The effect of 40-days low carbohydrate diet on $B M I\left[w t / h t^{2}\right]$ of participating medical students:

The regimen of 40-days low carbohydrate diet resulted in a statistical significant decrease in BMI of the study group $(29.43 \pm 2.96)$ compared to the baseline BMI mean $(31.65 \pm 3.08)$ as shown in Table (4).

Table (4): A comparison between study group BMI [wt/ht ${ }^{2}$ ] before and after 40 days of low carbohydrate diet.

\begin{tabular}{llllll}
\hline $\begin{array}{l}\text { BMI } \\
{[\mathrm{wt} / \mathrm{ht} 2]}\end{array}$ & Range & Mean \pm SD & $\begin{array}{c}\text { Mean } \\
\text { difference }\end{array}$ & $t$-test & $p$-value \\
\hline Before & $26.8-37.2$ & $31.65 \pm 3.08$ & 2.223 & 12.324 & $<0.001 * *$ \\
After & $24.5-36$ & $29.43 \pm 2.96$ & & & \\
\hline
\end{tabular}

The effect of 40-days low carbohydrate diet on Zinc level ( of participating medical students:

A 40-days low carbohydrate diet regimen resulted in a statistical significant increase in serum Zinc mean level of the study group (78.87 \pm 13.69$)$ compared to the baseline serum Zinc mean level (73.65 \pm 12.59$)$ as shown in Table (5). Normal level of serum zinc according to laboratory standards in males: $72.6-127 \mathrm{ug} / \mathrm{dl} \&$ in females: 70.6-114ug/dl. 
Table (5): A comparison between study group Zinc level ( $\mathrm{g} / \mathrm{d}$ ) before and after 40 days of low carbohydrate diet.

\begin{tabular}{|c|c|c|c|c|c|}
\hline $\begin{array}{l}\text { Zinc } \\
\text { level } \\
\text { (g/d) }\end{array}$ & Range & $\begin{array}{c}\text { Mean } \pm \\
\text { SD }\end{array}$ & $\begin{array}{c}\text { Mean } \\
\text { difference }\end{array}$ & $t$-test & $p$-value \\
\hline Before & $\begin{array}{l}53-98 \\
5 \mathrm{~g} / \mathrm{d}\end{array}$ & $\begin{array}{l}73.65 \pm \\
12.59\end{array}$ & 5.217 & 11.670 & $<0.001 * *$ \\
\hline After & $\begin{array}{l}55.65-102.9 \\
\mathrm{gg} / \mathrm{dL}\end{array}$ & $\begin{array}{l}78.87 \pm \\
13.69\end{array}$ & & & \\
\hline
\end{tabular}

\section{Discussion}

Nutritional disorders and obesity commonly co-exist, studies have attempted to clarify the disturbance in mineral metabolism in the presence of obesity. Zinc (Zn) was among the most important minerals highlighted in such studies, where it has been reported that $\mathrm{Zn}$ levels in plasma and erythrocytes were reduced in obese people whereas $\mathrm{Zn}$ supplementation improved various physiological functions in such patients [3]

Zinc, a divalent cation not synthesized within the human body, requires intake to maintain adequate levels. Deficiency can occur from decreased intake, inability to absorb the micronutrient, increased metabolic demand, or excessive loss. Endemic deficiency is common with up to one-third of the population in various parts of the world, primarily South east Asia and sub-Saharan Africa. Zn deficiency is also prevalent in Iran, Egypt, and Turkey secondary to high phytate intake [8]

Researches are being conducted with a view to investigate the role of minerals in protection against metabolic disorders associated with obesity. $\mathrm{Zn}$ in particular is an important inducer of insulin secretion, a sensitizer of insulin action, an anti-inflammatory and antioxidant agent [9] .

The present study, a randomized single arm open label clinical trial, was conducted to investigate the possible changes in serum $\mathrm{Zn}$ levels following a low carbohydrate diet program for 40 days in a group of overweight/obese medical students.

Thirty participants of overweight and obese medical students, 22 females and 8 males, were offered a 40-days low carbohydrate diet program with less than $26 \%$ of the total calories from carbohydrate on a weekly base tailored individually to meet the nutritional requirements, medical condition, food preferences, and socioeconomic status of each student. To our knowledge this is the first clinical study evaluating serum zinc levels before and after low carbohydrate diet in overweight and obese youth in Egypt.

Indeed, low serum $\mathrm{Zn}$ has been reported in obese individuals. A meta-analysis conducted by $\mathrm{Gu}$ and colleagues covering 15 studies in children and 8 studies in adults on obesity, reported that obese individuals had lower serum $\mathrm{Zn}$ level compared to control groups [10]

This goes hand in hand with the results of RiosLugo and colleagues who reported a lower serum $\mathrm{Zn}$ levels in overweight and obese individuals with no significant difference in $\mathrm{Zn}$ levels between males and females. They also reported a negative correlation between BMI and zinc levels regardless of sex [11]

According to the results of the current study, a 40-days low carbohydrate program resulted in a statistically significant reduction $(p>0.001)$ in the weight as well as BMI of the participating medical students. Moreover, serum zinc levels improved significantly ( $p>0.001)$ after the 40-days low carbohydrate program by $7.8 \%$ in comparison with its baseline levels before the start of the program.

Similar results were reported at the Institute of Nutrition Sciences, Tokyo, Japan, when a hypocaloric balanced diet was followed for 6 months by 23 obese females, who had a body mass index of more than 25 . The hypocaloric balanced diet significantly reduced the body weight, BMI, body fat percentage and amount of body fat along with an enhanced plasma concentration of zinc at the end of the program [4].

Paz-Tal et al., dietary intervention randomized control trial study applied low fat, Mediterranean, or Low carbohydrate diets over 2 years on 231 participants and followed for serum concentrations of zinc, copper, magnesium, and selenium. Serum zinc level exclusively was elevated mainly in lowfat diet group by decreasing intake of snacks, sweets, and cakes. Also the study of Paz-Tal et al., [12] concluded that comprehensive predictors for elevating zinc, copper, and selenium serum levels included decreasing consumption of sweets and cakes.

Ferro et al., [13] showed that there are alterations in biochemical parameters of Zinc in obese women. The levels of zinc in erythrocytes are influenced by components anthropometrics of Metabolic syndrome. The BMI and waist circumference showed a negative relation with this mineral. Moreover, there was no relationship between nutritional $\mathrm{Zn}$ 
status and the biochemical markers of Metabolic Syndrome.

On the other hand, Ostrowska et al., [14] study was conducted on a group of 48 women. Daily food rations were evaluated based on a week's dietary register to assess the realization of the reducing diet in the treatment of overweight or obesity $(1500 \mathrm{kcal})$ with regard to the caloric value and the content of basic nutrients, vitamins, and bioelements. The rations showed that the intake was too low in the case of zinc, iron and copper and it seems that long-term compliance with such a diet requires additional individual supplementation.

On the other hand New et al., [15] showed that Also, low carbohydrate diets are associated with a decreased consumption of fruits. This reduction is so marked that the diet should be completed with multivitamins supplementation.

Khorsandi et al., [16] clinical trial of zinc supplementation in 50 obese individuals who were referred to Diet and Nutrition clinic of Shahid Beheshti University of medical sciences showed that zinc supplementation with a restricted calorie diet has favorable effects in reducing anthropometric measurments, inflammatory markers, insulin resistance and appetite in individuals with obesity and may play an effective role in the treatment of obesity.

Martins et al., [3] done Cross sectional case control study involving 80 female obese participants aged between 20-59 years divided into two groups at federal University of Piaui. Experimental group's nutritional status based on Body mass index and waist circumference classified as obese in comparison to the other normal weight group. All groups subjected to assess their serum zinc level and ther was statistical significant difference seen in the biochemical parameters of zinc between the two groups mean serum zinc level in obese participants was lower than normal values [3].

\section{References}

1- World Health Organization: Obesity and overweight [Internet] World Health Organization; Geneva: 2020. Available from: http://www. who.int/news-room/factsheets/detail/ obesity-and-overweight, 2020.

2- SCHUTZ D.D., BUSETTO L., DICKER D., et al.: European practical and patient-centred guidelines for adult obesity management in primary care. Obesity Facts, 12: 40-66, 2019.

3- MARTINS L.M., de OLIVEIRA A.R., CRUZ K.J., de ARAÚJO C.G., de OLIVEIRA F.E., de SOUSA G.S., do
NASCIMENTO NOGUEIRA N. and do NASCIMENTO MARREIRO D.: Influence of cortisol on zinc metabolism in morbidly obese women. Nutricion Hospitalaria, 29 (1): 57-63, 2014.

4- ISHIKAWA Y., KUDO H., KAGAWA Y., et al.: Increased plasma levels of zinc in obese adult females on a weightloss program based on a hypocaloric balanced diet. In Vivo, 19: 1035-1037, 2005.

5- FRIEDMAN A.N., OGDEN L.G., FOSTER G.D., et al.: Comparative effects of low-carbohydrate high-protein versus low-fat diets on the kidney. Clinical Journal of the American Society of Nephrology, 7: 1103-1111, 2012.

6- SCOTT S.N., ANDERSON L., MORTON J.P., et al.: Carbohydrate Restriction in Type 1 Diabetes: A Realistic Therapy for Improved Glycaemic Control and Athletic Performance. Nutrients, 11: 1022, 2019.

7- LEAR S.A., JAMES P.T., KO G.T. and KUMANYIKA S.: Appropriateness of waist circumference and waist-tohip ratio cutoffs for different ethnic groups. European Journal of Clinical Nutrition, 64: 42-61, 2010.

8- MAXFIELD L. and CRANE J.S.: Zinc Deficiency. In: StatPearls [Internet]. Treasure Island (FL): StatPearls Publishing; PMID: 29630283, 2020.

9- KYRIA JAYANNE CLIMACO, MORAIS, CRUZ, JENNIFER BEATRIZ SILVA, de OLIVEIRA A.R., et al.: The Effect of Zinc Supplementation on Insulin Resistance in Obese Subject: A Systematic Review. Biol. Trace Elem Res., 176: 239-243, 2017.

10- GU K., XIANG W., ZHANG Y., SUN K. and JIANG X. The association between serum zinc level and overweight/ obesity: A meta-analysis. Eur. J. Nutr., 58 (8): 2971-2982, 2019.

11- RIOS-LUGO M.J., MADRIGAL-ARELLANO C., GAYTÁN-HERNÁNDEZ D., et al.: Association of Serum Zinc Levels in Overweight and Obesity. Biol. Trace Elem Res. Nov., 198 (1): 51-57, 2020.

12- PAZ-TAL O., CANFI A., MARKO R., et al.: Effect of changes in food groups intake on magnesium, zinc, copper, and selenium serum levels during 2 years of dietary intervention. J. Am. Coll. Nutr., 34 (1): 1-14, 2014.

13-FERRO F., de SOUSA LIMA V.B., MELLO SOARES N.R., et al.: Biomarkers of metabolic syndrome and its relationship with the zinc nutritional status in obese women. Nutr. Hosp. 26 (3): 650-4, 2011.

14- OSTROWSKA L., STEFANSKA E., CZAPSKA D. and KARCZEWSKI J.: Assessment of realization of a reducing diet by obese women during treatment of excessive body mass. Rocz Panstw Zakl Hig., 59 (3): 343-9, 2008.

15-NEW S.A., ROBINS S.P., CAMPBEL L.M.K., et al.: Dietary influences on bone mass and bone metabolism: Further evidence of a positive link between fruit and vegetable consumption and bone health? Am. J. Clin., 71: 124-151, 2000.

16- KHORSANDI H., NIKPAYAM O., YOUSEFI R., et al.: Zinc supplementation improves body weight management, inflammatory biomarkers and insulin resistance in individuals with obesity: A randomized, placebo-controlled, doubleblind trial. Diabetol. Metab. Syndr., 2 (11): 101, 2019. 


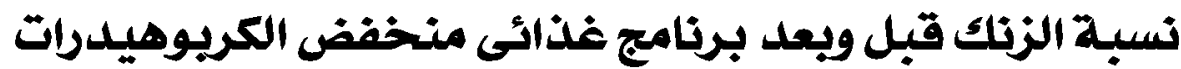

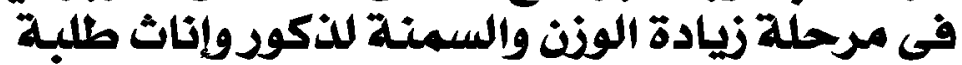

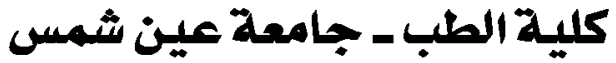

المقدمة: يعرف الهنف الزائد والسمنة على أنهما تراكم غير طبيعى أو مفرط للدهن قد يضر بالصحة. مؤثثر كتلة الجسم هو مؤثر بسيط

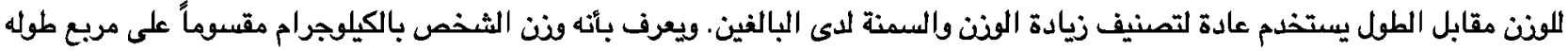

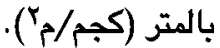

الهدف من الدراسة: أجريت دراستنا لتقييم مستوى الزنك فى الدم قبل وبعد برنامج غذائى منخفض الكربوهيدرات على مدى .ع يوماً.

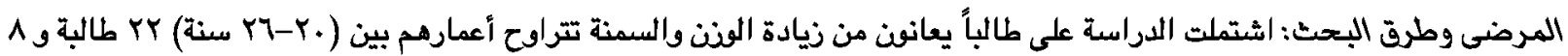

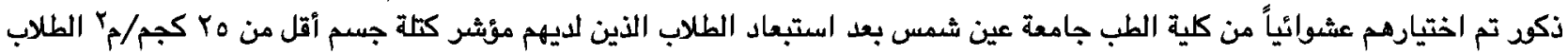

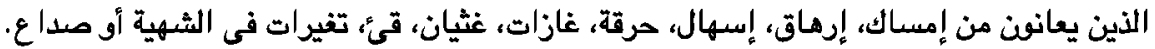

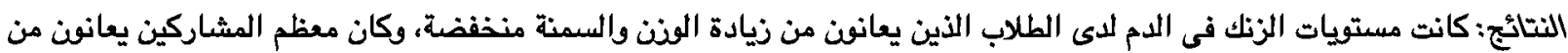

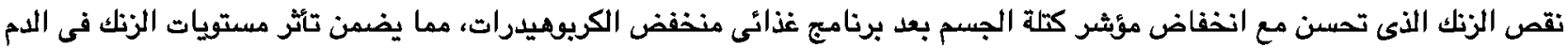

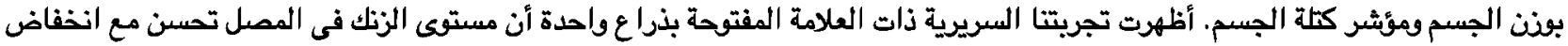

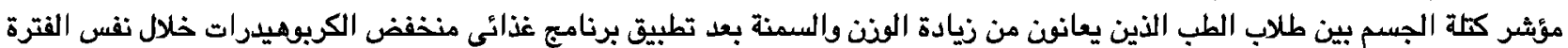

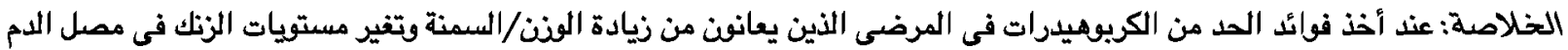

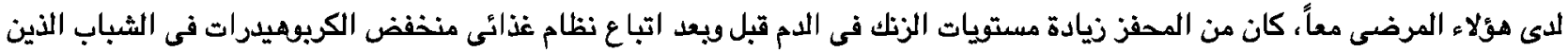

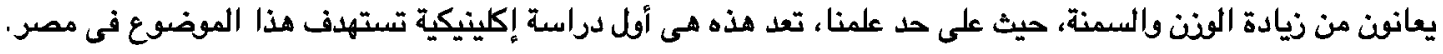

